\title{
BEHAVIORAL INTENTION ANALYSIS ON INTERNET BANKING USAGE AT BANK XYZ BOGOR
}

\author{
Fitria Annilda*)1, Ujang Sumarwan**), and Endar Nugrahani**) \\ *) School of Business, Bogor Agricultural University \\ Jl. Raya Pajajaran, Bogor 16151 \\ ${ }^{* *}$ Department of Family and Consumer Sciences, Faculty of Human Ecology, Bogor Agricultural University \\ GMSK Building Floor 2, Dramaga Campus IPB 16680 \\ ${ }^{* *}$ Department of Statistics, Faculty of Mathematics and Natural Sciences, Bogor Agricultural University \\ Jl. Meranti Wing 22 Level 4, Dramaga Campus IPB 16680
}

\begin{abstract}
The aims of this paper were to analyze the customer decision to use internet banking and to anlyze the factors correlated with the intention of internet banking usage at XYZ Bank, Bogor, Indonesia. The theoretical foundation for this study was Theory of Planned Behavior (TPB). TPB is a model that estimates the consumers' intention to perform a behavior or action. A number of 150 respondents were selected by convenience sampling method using questionnaires with interviews. The data were analyzed using SEM-PLS. The results showed that perceived behavior control had a significant influence on behavioral intention. Respondents who had higher scores of perceived behavior were more likely to have a higher intention of using internet banking. For the managerial implications, the company is expected to provide more user-friendly and attractive facilities for users, so that users can easily do banking transactions without having to queue at either a Bank or ATM counters. Second, the facility with more limit than that exists now can be used as a reference for the company to increase the number of internet banking users, so users can use facilities safely, and desired facilities are available in internet banking.
\end{abstract}

Keywords: behaviour intention, internet banking, SEM-PLS, theory of planned behavior

\begin{abstract}
Abstrak: Tujuan penulisan ini adalah untuk menganalisa penggunaan internet banking banking nasabah di XYZ Bogor, Indonesia. Landasan teoritis untuk penelitian ini adalah Theory of Planned Behavior (TPB). TPB adalah model yang memperkirakan niat konsumen untuk melakukan perilaku atau tindakan. Jumlah sampel sebanyak 150 responden yang dipilih dengan metode convenience sampling menggunakan kuesioner dengan wawancara. Data dianalisis menggunakan SEM-PLS. Hasil penelitian menunjukkan bahwa perceived behavior control berpengaruh signifikan terhadap behavioral intention. Responden yang lebih cenderung memiliki niat lebih tinggi menggunakan internet banking. Implikasi manajerialnya adalah bahwa perusahaan diharapkan dapat memberikan fasilitas yang lebih mudah dan menarik bagi pengguna sehingga pengguna dapat dengan mudah melakukan transaksi perbankan tanpa harus mengantri ke counter Bank atau ATM. Kedua, fasilitas dengan batas lebih pada pengguna internet banking, sehingga pengguna bisa memanfaatkan fasilitas tersebut.
\end{abstract}

Kata kunci: behaviour intention, internet banking, SEM-PLS, theory of planned behavior

\footnotetext{
${ }^{1}$ Corresponding author:

Email: annildafitria@yahoo.com
} 


\section{INTRODUCTION}

Nowadays there are a lot of competitions in the banking sector in providing added value to customers through similar strategies. Therefore, a bank should be able to maintain its added value by managing longterm relationships with its customers (Aviliani et al. 2011). One of the bank's efforts to provide added value to customers is through electronic banking. There are two types of electronic banking (e-banking), namely $\mathrm{m}$-banking and internet banking. E-banking is a facility provided by each bank for customers' convenience in conducting banking transaction. Customers do not have to come to the bank or ATM. The e-banking transaction, particularly in this case the internet banking facility, is defined as e-banking facility which enables transactions, payments and other transactions via internet connection through a website owned by the bank equipped with a security system. Today, more banks provide internet banking service which is set by the Regulation of Bank of Indonesia No.9/15/PBI/2007 of 2007 on the implementation of risk management in the use of information technology by commercial banks. The implementation of internet banking is the application of information technology which continues to develop and is used to fulfil the wishes of bank customers who want a quick, safe, convenient, and inexpensive service that is available at any time ( 24 hours/day, 7 days/week) and can be accessed from anywhere, from cellphone, computer, laptop, and others.

Mayasari et al. (2011) shows that perception of the ease of use is an antecedent variable of customers' attitude in using internet banking; however, perception of benefit is not an antecedent variable of customers' attitude in using internet banking although respondents feel that internet banking has provided benefits in their work. However, this result did not improve the attitude to reuse the internet banking considering users have a role to the use and intensity of internet banking. Based on the research conducted, there are things that have not been carried out by the previous researchers concerning the intention of internet banking users. Previous researchers only examined the attitudes of users and did not examine the intention of internet banking users as well as factors causing the users to continue being interested in using internet banking.

This study was conducted based on the background of queueing found in the banking halls and ATM areas and the previous study which only examined the attitude of internet banking users as well. The results of Anggraeni and Yasa (2012) with the title e-quality of service satisfaction and customers' loyalty to use internet banking showed that the quality of service from e-banking positively and significantly influenced customer's satisfaction, meaning the better the quality of internet service, the higher the customer's satisfaction. Also according to Manalu et al. (2007) a community forum online efforts have also provided the best service to meet the customer's satisfaction.

According to the data of 2014 and 2015, the number of internet banking users of XYZ Bank branch Bogor increased slightly. If compared to non-users, internet banking users of XYZ Bank are not comparable to the non-users (Table 1). Data show that the number of non-users is higher than the Internet Banking users, which may lead to the increase of queues in the banks and ATM areas. Therefore, it is necessary to analyze the behavior of internet banking users with regard to factors affecting the use of internet banking to reduce the impact of queueing found in the banks and ATM areas.

XYZ Bank has the most diverse banking products in Indonesia. With a broad and diverse electronic banking service network, it will be convenient and easy for customers to perform a banking transaction. One product provided by XYZ Bank is e-banking consisting of m-banking and internet banking. In this research, banking facility observed was the internet banking. Since convenience and ease of service are everything, internet banking becomes electronic banking products offered to facilitate banking transactions. Attitude is an individual feeling or influence of response perceived by someone to an object. Later, the attitude formed will affect the intention of a person to behave in certain ways. High intention in internet banking tends to make the customers use internet banking facilities; hence, factors contributing to the intention in the continuous use of internet banking are important information for management to obtain.

Table 1. Data of internet banking users and non-users of XYZ Bank branch Bogor

\begin{tabular}{cccc}
\hline Year & $\begin{array}{c}\text { Number of } \\
\text { Customer } \\
\text { (thousand } \\
\text { people) }\end{array}$ & $\begin{array}{c}\text { User } \\
\text { (thousand } \\
\text { people) }\end{array}$ & $\begin{array}{c}\text { Non-User } \\
\text { (thousand } \\
\text { people) }\end{array}$ \\
\hline 2014 & 5,000 & 2,190 & 2,810 \\
2015 & 5,395 & 2,310 & 3,085 \\
\hline
\end{tabular}


In reference to the issues faced by XYZ Bank, the objectives of this study were to identify customer's decision to use internet banking and to analyze the factors that were correlated to the intention of internet banking usage at XYZ Bank Bogor based on the theory of planned behavior (TPB), using a structural equation modelling with partial least square method (SEM-PLS). Some related researches, i.e., Makokha (2012), Haryono et al. (2012), Knabe (2012), Damayanti (2012), Ahmad et al. (2013), Sulistiyarini (2013), Hidayati (2013), and Rismanto et al. (2013) used the same method as this study, i.e. utilizing the Theory of Planned Behaviour (TPB) approach.

There are several studies that serve as benchmarks in this study. Firstly, the study on the internet banking users' attitude, the literature study conducted by Tan and Teo (2000), Baraghani (2007), Maenpaa (2010), Aderonke (2010) explained the use of internet banking in addition to factors of usability and easeness. Secondly, the study on trust and motivation of internet banking users conducted by Saleh (2003), Kassim and Amka (2006), Widiastuti (2010), Rogers (2010), Alnsour (2010), and Akhlaq (2013) found that trust and motivation had a positive effect on the adoption of internet banking. In addition, factors impacting the customers' decisions to adopt internet banking conducted by Molapo (2008), Nasri (2011), Amalia et al. (2012), and Clemes et al. (2012) show that variables of ease of site, ease of internet, security, oral marketing, price, ease of access, marketing, and self-image resulted in the factor of the eight independent variables that affected the adoption of the internet banking usage positively. Thirdly, the study on the quality of internet banking services and the level of satisfaction on customer loyalty conducted by Huda and Wahyuni (2012), Butar-Butar (2013) concluded that the site display or website display and design that fitted with the site or website affected the customer's satisfaction on internet banking positively.

There are differences and similarities between this study and the previous studies. The similarities of the study can be seen from the similar title and the methods of analysis used in the customers' perceptions or attitudes as internet banking users and the SEM analysis method. There is also a difference in this study, that is the study conducted by Tan and Teo (2000) used Cronbach method, while Maenpaa (2010) used cluster analysis method, quartile analysis and ANOVA. However, Mayasari (2011) and Aderonke (2010) used the same analysis, namely multiple linear regressions. Besides that, the difference of these researches was in the title used. This research studied the attitude of internet banking users, whereas the research by Butar-Butar (2013) was about the level of customer's satisfaction of the service of internet banking products, the research by Widiastuti (2010) about the intensity of the use of internet banking, and the research by Akhlaq (2013) about the effect of motivation of trust of the use of internet banking.

According to Sanjaya et al. (2015), the company requires a right way to know its customers according to the customers' needs and desires. High intention of internet banking tends to make the customers use internet banking facilities; therefore, the factors that contribute to the interest of internet banking use in a sustainable manner is a major point for management to know. The objectives of this study were to identify customer's decision to use internet banking and to analyze factors that were correlated to the intention of internet banking usage at XYZ Bank Bogor.

The scope of this study is limited to the existing problems and the level of active account holders with an age limit between 20-50 years. The attitude of consumer or customer is focused on the intention of consumer or customer of XYZ Bank Bogor branch.

\section{METHODS}

This study was conducted at XYZ Bank located in Bogor, West Java from October to November 2016. Bogor city was selected due to the fact that the number of internet banking users tended to be lower than that of non-users. This research was conducted by using survey through questionnaire distribution and interview. Data and information obtained from the research were described based on the research objective. This study used primary and secondary data. Primary data were data directly obtained from respondents through questionnaire. Secondary data came from XYZ Bank, internet, magazines, and results of previous studies. Data collection technique in this study used a structured questionnaire instrument. Types of questions used were closed and open questions. Several questions in the questionnaire were made based on Likert scale with five variations of response from strongly disagree to strongly agree. Data collection was done by performing face to face interviews with the respondents. 
A number of 150 respondents were selected by convenience sampling method. Data analyses used descriptive statistics to answer the objective concerning the decision-making to use the internet banking, while analysis of multivariate (SEM-PLS) was used to examine the correlation of independent variables on intention of internet banking users. SEMPLS is a powerful analytical method since it can be applied to all types of data scale including nominal, category, ordinal, interval and ratio; thus, it does not assume data with certain distribution (Ghozali, 2008). There are two models estimated in the SEM model in this study, namely structural model and measurement model. Structural model is aimed to explain the interrelationship (influence) between latent variables. Moreover, measurement model is aimed to explain the inter-relationship between a latent variable and its indicator variables.

The theory of Planned Behavior (TPB) is composed of three exogenous latent variables, which are behavioral belief, evaluation of outcome, normative belief, motivation to comply, control belief, power of control factor. However, there is one indigenous latent variable, that is consumer's intention to continue using internet banking facility for the next 6 (six) months. Formally, formulation of mathematical model of intention in using internet banking developed in this study is presented in Equation:

$$
\mathrm{BI}=\mathrm{Aact}(\mathrm{w} 1)+\mathrm{SN}(\mathrm{w} 2)+\mathrm{PBC}(\mathrm{w} 3)
$$

Description: BI (behavioral intention in using internet banking); Aact (attitude to behavior of using internet banking); SN (subjective norm); PBC (perceived behavioral control); $\mathrm{W}$ (weight reflecting the influence)

Moreover, behaviour intention of internet banking usage at XYZ Bank is included in the dependent variable. Variables forming intention of internet banking users can be seen in Table 2. The hypothesis test used to know factors that have significant correlation with the behaviour intention of internet banking usage at XYZ Bank. The research framework can be seen in Figure 1. The hypothesis tested in this research is:

H1 : Attitude to Behavior has significant correlation to the behavior intention
H2 : Subjective Norms have significant correlation to the behavior intention

H3 : Perceived Behavioral Control has significant correlation to the behavior intention

\section{RESULTS}

\section{Decision Analysis of Using Internet Banking}

According to Sumarwan (2011), consumer behavior tries to understand how consumers search, purchase, use, evaluate and spend products and services. Each consumer makes various decisions to search, purchase, and use a variety of products and brands in a certain period.

\section{Attitude to the Internet Banking Users' Behavior}

Table 3 shows the attitudes to the internet banking users' behavior. It is shown that $44.0 \%$ of respondents were neutral in using internet banking facility for an amount greater than other electronic banking facility limit. In terms of time-saving using the internet banking facility, it was obtained that $51.3 \%$ of the respondents agreed that the use of internet banking facility could save time. In terms of speed of internet banking facilities compared to other electronic banking facilities, the result showed that $46 \%$ of the respondents agreed if the internet banking facility worked faster than other electronic banking facilities. In terms of security of internet banking facility, $49.3 \%$ of the respondents agreed that the internet banking facility was safely used. Fourty-four percent of respondents agreed that internet banking gave more facilities compared to other electronic services.

The result of the evaluation of internet banking usage, the importance to do large transactions using internet banking facility, showed that $39.3 \%$ of respondents was neutral, meaning that these respondents still thought that large transactions could be done not only by internet banking facility but also by coming to the counter (Table 3 ). In addition, in terms of timesaving, $49.3 \%$ of respondents agreed that using internet banking facility is important for them, because it can save time without queueing at the counter. As much as $45.3 \%$ of respondents agreed that it is important to use internet banking facility as it can be faster in doing banking facilities. In the aspect of security, $42.7 \%$ of respondents agreed on the importance of this 
factor in banking transactions. Fourty-seven percent of respondents agreed that more facilities were available than other banking electronic, and it was very important to provide easiness to customers.

\section{Attitude to the Subjective Norms}

In terms of normative belief, $40.7 \%$ of respondents agreed that the use of internet banking facility is recommended by a bank officer (Table 4 ), 38\% by a business associate, and $36 \%$ by others. This illustrates that internet banking is a facility that can be used by anyone. In terms of motivation to comply with suggestion, $42.7 \%$ of respondents agreed to comply with the suggestion from the bank officers to use internet banking, 40\% agreed to comply the suggestion from business associates and $37.3 \%$ agreed to comply with the suggestion from other parties (Table 4). This illustrates that the suggestion to use internet banking has many positive responses, meaning that internet banking can make banking transactions easier to do without queueing either at a counter or at an ATM.

Table 2. Construct, dimension, and indicator used

\begin{tabular}{|c|c|c|c|}
\hline Construct & Dimension & Indicator & Scale \\
\hline \multirow[t]{10}{*}{ Attitude to Behavior } & Behavioral belief & Large transaction & Interval \\
\hline & & Saving time & Interval \\
\hline & & Fast network & Interval \\
\hline & & Secure transaction & Interval \\
\hline & & More complete facility & Interval \\
\hline & Outcome evaluation & Large transaction is important & Interval \\
\hline & & Saving time iintentions important & Interval \\
\hline & & Fast network is important & Interval \\
\hline & & Secure transaction is important & Interval \\
\hline & & More complete facility is important & Interval \\
\hline \multirow[t]{6}{*}{ Subjective Norms } & Normative belief & Recommendation from bank officer & Interval \\
\hline & & Recommendation from business colleague & Interval \\
\hline & & Recommendation from the others & Interval \\
\hline & Motivation to comply & Follow the recommendation from bank & Interval \\
\hline & & Follow the recommendation from colleague & Interval \\
\hline & & Follow the recommendation from other party & Interval \\
\hline \multirow{10}{*}{$\begin{array}{l}\text { Perceived Behavioral } \\
\text { Control }\end{array}$} & Control belief & Large transaction $<6$ months & Interval \\
\hline & & Busy $<6$ months & Interval \\
\hline & & Various transactions $<6$ months & Interval \\
\hline & & E-Transaction $<6$ months & Interval \\
\hline & & Learn the facility $<6$ months & Interval \\
\hline & Control factor & Will perform large transaction & Interval \\
\hline & & Busy at work & Interval \\
\hline & & A lot of transaction & Interval \\
\hline & & E-transaction & Interval \\
\hline & & Easiness & Interval \\
\hline Behavioral Intention & & Intention & Interval \\
\hline
\end{tabular}




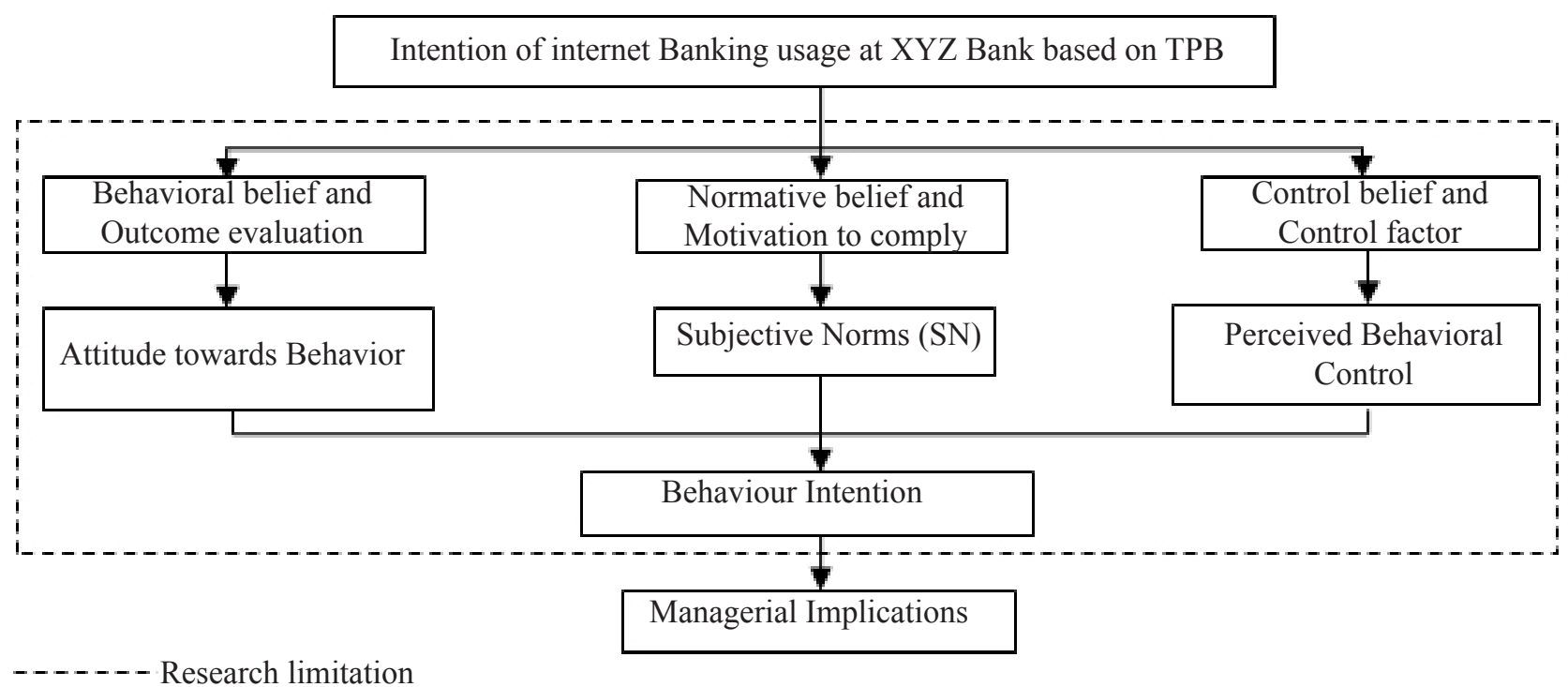

Figure 1. Research framework

Table 3. Attitudes to the internet banking users' behavior

\begin{tabular}{llcc}
\hline \multicolumn{1}{c}{ Dimension } & \multicolumn{1}{c}{ Indicator } & Percentage & Category \\
\hline Behavioral belief & Be able to perform larger banking transaction & 44.0 & Neutral \\
& Be able to save time in performing banking transaction & 51.3 & Agree \\
& Be able to perform faster banking transaction & 46.0 & Agree \\
& Be able to perform more secure banking transaction & 49.3 & Agree \\
& Receives more complete transaction service & 44.0 & Agree \\
Evaluation of & Banking transaction in larger amount is important & 39.3 & Neutral \\
outcome & Time saving in performing banking transaction is important & 49.3 & Agree \\
& Performing fast banking transaction is very important & 45.3 & Agree \\
& Performing more secure banking transaction is very important & 42.7 & Agree \\
& Receiving more complete banking transaction is very important & 47.3 & Agree \\
\hline
\end{tabular}

Table 4. Attitude to the subjective norms

\begin{tabular}{llcc}
\hline \multicolumn{1}{c}{ Dimension } & \multicolumn{1}{c}{ Indicator } & Percentage & Category \\
\hline Normative belief & Bank officer recommends to use internet banking & 40.7 & Agree \\
& Colleague recommends to use internet banking & 38.0 & Agree \\
& Other party recommends to use internet banking & 36.0 & Agree \\
Motivation to & Follow the recommendation from bank officer to use internet banking & 42.7 & Agree \\
comply & Follow the recommendation from my business colleague to use internet & 40.0 & Agree \\
& banking & & \\
& Follow the recommendation from other party to use internet banking & 37.3 & Agree \\
\hline
\end{tabular}

Based on the attitudes to behavioral control in the use of internet banking facility, $42.7 \%$ of respondents was neutral in doing large banking transactions using the internet banking facility in the next 6 (six) months (Table 5). This is because the respondents thought they can do large banking transactions by coming to a bank counter during a period of 6 (six) months. In terms of respondents' rush in the next 6 (six) months, $40.7 \%$ of respondents agreed to it so that the use of internet banking was very possible because of this factor. The use of internet banking facilities in the next 6 (six) months because of various kinds of internet banking facilities, $44.7 \%$ of respondents was neutral, this indicates that there are more variety of facilities than other e-banking service facilities, respondents could still use other than internet banking facility. In terms 
of frequency of doing transactions using e-banking, $41.3 \%$ of respondents agreed, meaning that e-banking has become a facility that makes banking transactions easier to do without requiring the respondents queue at a counter. In the terms of the respondents who will study internet banking facility for the next 6 months, $47.3 \%$ of respondents agreed that they had learnt about internet banking as realizing the ease of use and comfort of the facility so that it can save time without requiring queuing at a counter.

In terms of control factors over the use of internet banking facilities, $38 \%$ of respondents agreed that the large transactions could be done with internet banking facility, even though in addition to internet banking, large banking transactions could be done at the counter where the transaction was done, if it did exceed the limit of internet banking facility (Table 5). As much as $53.3 \%$ of respondents agreed that using internet banking facility would save time if the respondent was getting busy. As much as $48 \%$ agreed that the more facilities on the internet banking would make the respondents use internet banking other than other e-banking services. As much as $53.3 \%$ of respondents agreed that internet banking was an e-banking service they would use to do banking transactions compared with other e-banking services. As much as $52.7 \%$ of respondents agreed that they would use the internet banking facility on a regular basis if the ease of use internet banking was the same as other e-banking services.

In terms of the percentage of behavioral intentions, respondents who would use the internet banking facility for the next 6 (six) months was only $10.7 \%$ of customers approved. This represents that the internet banking will not necessarily be used if the customers do not really need the internet banking facility, meaning they prefer to keep queueing at a counter or an ATM. This can be influenced because they lack the information about internet banking; the facility as well as other factors is too difficult to learn so that customers still want to queue at a counter or at an ATM.

Factors Forming the Internet Banking Users' Intention Figure 2 shows that all indicators have loading factor value $>0.5$, which means that all indicators have met the criteria of convergent validity test of latent construct (Ghozali, 2008). In addition, analysis result also shows that AVE value of each latent variable exceeds 0.5. Moreover, value of composite reliability and cronbach alpha of each latent construct is higher than 0.6. Therefore, PLS model has met the validity criteria of good convergent, good reliability, accuracy and consistency.

Bootstrapping result in Table 6 shows that perceived behavioral control is significantly correlated with the behavioral intention with t-statistic value of (2.696) $>$ t-table (1.96) at 5\% significance level. Moreover, attitude to behavior of user and subjective norm does not show any correlation with the behavioral intention as $\mathrm{t}$-statistics value $\leq \mathrm{t}$-table (1.96). Perceived behavioral control has a correlation with the behavioral intention of 0.336 which means that increasing perceived behavior control of a person over internet banking will further increase the intention of internet banking.

Table 5. Percentage of attitude to behavioral control

\begin{tabular}{|c|c|c|c|}
\hline Dimension & Indicator & Percentage & Category \\
\hline \multirow[t]{5}{*}{ Control belief } & Within the next 6 months will perform larger transaction & 42.7 & Neutral \\
\hline & Within the next 6 months will be busy & 40.7 & Agree \\
\hline & Within the next 6 months will perform various banking transactions & 44.7 & Neutral \\
\hline & Within the next 6 months will perform a lot of electronic transactions & 41.3 & Agree \\
\hline & Within the next 6 months will learn about internet banking & 47.3 & Agree \\
\hline \multirow[t]{5}{*}{ Control factor } & Use internet banking if performing larger transaction & 38.0 & Agree \\
\hline & Use internet banking if getting busy & 53.3 & Agree \\
\hline & Use internet banking if performing more banking transaction & 48.0 & Agree \\
\hline & Use internet banking if performing electronic transaction & 53.3 & Agree \\
\hline & $\begin{array}{l}\text { Use internet banking ifinternet banking transactionis as easy as other } \\
\text { electronic banking }\end{array}$ & 52.7 & Agree \\
\hline
\end{tabular}




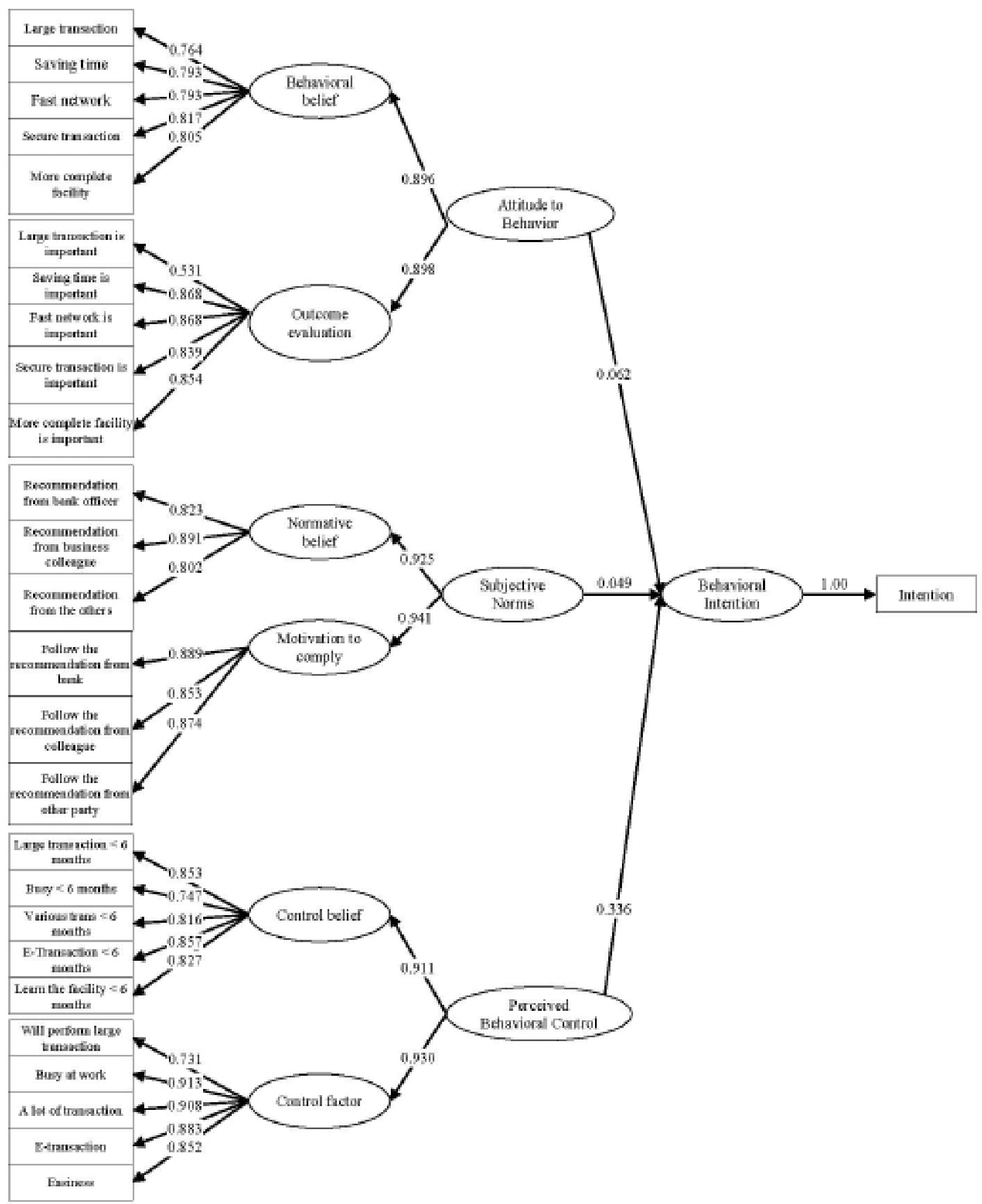

Figure 2. Model of SEM 
Table 6. Value of loading factor and t-statistic

\begin{tabular}{|c|c|c|c|}
\hline & Loading factor & T-statistic & R-square \\
\hline Attitude to behavior of user $\rightarrow$ User intention & 0.062 & 0.674 & 17.40 \\
\hline Subjective norm $\rightarrow$ User intention & 0.049 & 0.397 & \\
\hline Perceived behavioral control $\rightarrow$ User intention & 0.336 & 2.696 & \\
\hline
\end{tabular}

These results indicate that customers' behavior intention of internet banking is highly dependent on the needs of customers, where customers are increasingly busy with the needs of banking transactions, and the number of transactions in the bank will further increase customers' intention of internet banking because of usability and easeness factors. These results are in line with the study by Aderonke (2010) that concluded that the use of internet banking in addition to factors of usability and easeness in fact the credibility of the system and the computer was one of the factors that was taken into account by internet banking users. This structural model of theory of planned behavior results in R-square value of $17.40 \%$ reflecting that the variance of internet banking behavioral intention which can be explained by the model is $17.40 \%$, while the remaining $82.60 \%$ is explained by other factors outside the model.

\section{Managerial Implications}

Internet banking is one of the facilities of banking product created to facilitate customers in performing banking transaction without having to queue at the bank or ATM counter. Research result shows several studies that can be conducted by XYZ Bank. Those are:

1. The company is expected to provide easier and more attractive facilities for users since evaluation result shows that the customers' intention of the use of internet banking is great. The company can create a secure and more easy-to-use internet banking which will certainly affect the service at the branch where maximum convenience is able to be given as customers do not need to wait for their turn in a long queue to perform other banking transaction which cannot be done through internet banking.

2. Facilities with more limit than what exists now may be used as a reference for the company to increase the number of internet banking users. In addition, due to the implementation of security through a tool called internet banking key, users can safely use the internet banking facilities with desired facilities already available in internet banking.

3. To overcome the business factor and the number of transactions that will be conducted by customers through internet banking, company should be more intensive in promoting internet banking either through information by bank officer, communication media such as television put in the banking area, or media brochure that the bank officer can give to the customers when they are waiting in the banking area.

\section{CONCLUSIONS AND RECOMMENDATIONS}

\section{Conclusions}

Based on the research result, it can be concluded that by considering the attitude of customers, it is shown that internet banking receives a good response in terms of internet banking facilities, convenience, safety, needs, driving factors and factors of reliability of internet banking facility as seen from the percentage of each questionnaire answered by respondents.

Intention in internet banking analyzed using the TPB theory approach leads to a conclusion that internet banking users are intentions in using internet banking facility based on the perceived behavior control. It means that internet banking users are affected by users' needs of internet banking facilities and other factors such as occupation, the age of users, working environment, intention to learn and other factors which may influence other factors than the need to use the internet banking facility.

\section{Recommendations}

Recommendation in this research is intended to increase the users' intention of internet banking facilities in XYZ Bank Bogor by informing that the internet banking facility is an easily understood term to customers, especially in terms of safety and convenience provided by internet banking facility. Therefore, users' intentions are not only based on their needs but also on other factors which can affect them in using internet banking facility. Later, queues at the bank counter and ATM area can be reduced with further improvement in the bank service in all service aspects and banking products. 
This study only evaluates factors that are correlated with the intention of internet banking usage by performing TPB theoretical approach and SEM analysis. Further research can be developed by examining which market segment of customer that will most likely be influential and which has high potential in using internet banking, because by knowing the right market segment it will be easy to know the customers' intention in using internet banking.

\section{REFERENCES}

Aderonke A. 2010. An empirical investigation of the level of users' acceptance of e-banking in Nigeria. Journal of Internet Banking and Commerce 1(15): 1-13.

Ahmad M, Kadir AS, Salehudin AN. 2013. Perceptions and behavior's of muslims and nonmuslimstowards halal products. Journal of Social and Development Sciences 4(6): 249-257.

Akhlaq A, Ahmed E. 2013. The effect of motivation on trust in the acceptance of internet banking in a low income country. International Journal of Bank Marketing 31(2): 1-12. https://doi. org/10.1108/02652321311298690.

Alnsour MS. 2011. Internet banking and jordanian corporate customers: issues of security and trust. Journal of Internet Banking and Commerce 16(1): 1-15.

Amalia M, Mudjahidin, Anggraeni W. 2012. Analisis faktor penyebab kepuasan pelanggan terhadap penggunaan internet banking berdasarkan efek pengalaman dengan metode partial least square [studi kasus: Bank Swasta dan Bank BUMN]. Jurnal Teknik Pomits 1(1): 1-6.

Anggraeni NMS, Yasa NNK. 2012. E-service quality terhadap kepuasan dan loyalitas pelanggan dalam penggunaan internet banking. Jurnal Keuangan dan Perbankan 16(2): 293-306.

Aviliani, Sumarwan U, Sugema I, dan Saefudin A. 2011. Segmentasi nasabah tabungan mikro berdasarkan recency, frequency, dan monetary: kasus bank BRI. Finance and Banking Journal 13(1): 95-109.

Baraghani SN. 2007. Factors influencing the adoption of internet banking [tesis]. Lulea: Lulea University of Technology.

Butar-Butar R. 2013. Analisis tingkat kepuasan nasabah terhadap pelayanan produk internet banking di bank Danamon [tesis]. Bogor:Sekolah
Pascasarjana Institut Pertanian Bogor.

Clemes MD, Gan C, Du J. 2012. The factors impacting on customers' decisions to adopt internet banking. Banks and Bank Systems 7(3): 1-13.

Damayanti TW. 2012. Changes on Indonesia tax culture,is there aaay? Studies through thoery of planned behaviour. International Refereed Research Journal 3(4): 1-8.

Ghozali I. 2008. Structural Equation Modeling Metode Alternatif dengan Partial Least Square (PLS). Semarang: UNDIP.

Haryono T, Sumarwan U, Saefuddin A, Hartoyo. 2012. Structural model of factors influencing consumers intention to use natural gas: an application of planned behaviour theory. Journal of Educational Research and Review 1(10): 244-252.

Hidayati NA. 2013. Pengaruh sikap, kontrol perilaku persepsian, pengalaman dan kepercayaan terhadap minatmenggunakan layanan internet banking. Jurnal Ilmiah FEB 2(2): 1-24.

Huda AN, Wahyuni S. 2012. Analisis pengaruh kualitas layanan internet banking dan tingkat kepuasan terhadap loyalitas nasabah pada PT Bank Rakyat Indonesia (Persero) Tbk kantor cabang pembantu Jamsostek Jakarta. Business and Management Review 2(2):1-12.

Kassim NM, Abdulla AKMA. 2006. The influence of attraction on internet banking: an extension to the trust-relationship commitment model. International Journal of Bank Marketing 24(6): $1-20$.

Knabe A. 2009. Applying Ajzen's Theory of Planned Behavior to a Study of Online Course Adoption in Public Relations Education. Milwaukee: Marquette University.

Maenpaa K. 2010. User perceptions of internet banking [disertasi].Tampere: University of Tampere.

Makokha LW. 2012. Evaluating Behavioural Intentions In The Adoption Of Internet Banking. Nairobi: University of Nairobi.

Manalu ASB, Sumarwan U And Suroso AI. 2007. Analisis faktor-faktor yang mempengaruhi kepuasan pelanggan online. Jurnal Manajemen dan Agribisnis 4(2): 67-80.

Mayasari F, Kurniawati EP, Nugroho PI. 2011. Anteseden dan konsekuen sikap nasabah dalam menggunakan internet banking dengan menggunakan kerangka Technology Acceptance Model (TAM) (survey pada pengguna klik BCA). Dalam Seminar Nasional Teknologi Informasi 
\&Komunikasi Terapan; 2011, Seminar Nasional, down load internet Maret 2016 URI:http:// eprints.dinus.ac.id/id/eprint/23.

Molapo MN. 2008. An assesment of internet banking service quality [disertasi]. Johannesburg: University of Johannesburg.

Nasri W. 2011. Factors influencing the adoption of internet banking in Tunisia. International Journal of Business and Management 6(8): 1-13. https:// doi.org/10.5539/ijbm.v6n8p143.

Rismanto, Wiyono A, Wachyuni S. 2013. Kajian peran rerta petani dalam operasi dan pemeliharaan infrastruktur jaringan irigasi dengan pendekatan Theory of Planned Behaviour (TPB). Jurnal Sosioteknologi 30(12): 1-25.

Rogers M. 2010. Consumers attitudes perceived risk, trust and internet banking adoption in Uganda [disertasi]. Kampala: Makerere University.

Saleh ZI. 2003. An Examination of The Internet Security And Its Impact on Trust And Adoption of Online Banking. Minneapolis:Capella University.
Sanjaya R, Sumarwan U, Kirbrandoko. 2015. Hubungan customer relationship management dengan loyalitas nasabah (Studi kasus: PT Bank XYZ Cabang Bogor. Manajemen IKM 10(2): $151-162$.

Sulistiyarini S. 2013. Pengaruh minat individu terhadap penggunaan mobile banking: model kombinasi technology acceptance model (TAM) dan theory of planned behaviour (TPB). Jurnal Ilmiah FEB 1(2): 1-20.

Sumarwan U. 2011. Perilaku Konsumen Teori dan Penerapannya dalam Pemasaran. Ed ke-2. Bogor: Penerbit Ghalia Indonesia.

Tan M, Teo TSH. 2000. Factors influencing the adoption of internet banking. Journal of the Association for Information Systems1(2): 1-44. https://doi. org/10.17705/1jais.00005.

Widiastuti B. 2010. Studi tentang intensitas penggunaan electronic banking oleh nasabah PT Bank Central Asia,Tbk (BCA) kantor cabang utama Semarang [tesis]. Semarang: Universitas Diponegoro. 